\title{
Institutional shareholdings and corporate dividend policy in Pakistan
}

\author{
Talat Afza ${ }^{1}$ and Hammad Hassan Mirza ${ }^{2 \star}$ \\ ${ }^{1}$ COMSATS Institute of Information Technology, Lahore, Pakistan. \\ ${ }^{2}$ Department of Business Administration, University of Sargodha, Sargodha 40100, Pakistan. \\ Accepted 27 May, 2011
}

\begin{abstract}
The present study investigates the impact of institutional ownership and growth opportunities on dividend policy based on the sample of 120 Listed Companies of Karachi Stock Exchange (KSE), Pakistan, during 2002 to 2007. The estimated results, using OLS and Tobit regression models, suggest that dividend payouts are positively affected by growth opportunities, proportion of shares held by insurance companies and profitability and negatively affected by leverage. However, no significant impact of ownership by Modarbah, NIT and miscellaneous institutions on dividend payout is observed. Large companies are less likely to pay high dividends but the relationship of size with dividend payout is insignificant. Estimated results are robust to alternative proxy of dividend policy that is, Dividend Intensity.
\end{abstract}

Key words: Dividend policy, growth opportunities, institutional ownership, Tobit regression.

\section{INTRODUCTION}

Corporate dividend decision is among the important financial decisions for the management. Dividend payout is not only the source of cash flow to the shareholders but it also provides information regarding firm's current and future performance. There is an emerging consensus among financial researchers that no single factor affects corporate dividend decision. The inconclusiveness of empirical findings on determinants of dividend policy has made the issue more complex. However, the agency cost perspective of corporate payouts has gained significant importance during the last few decades.

The existing literature supports the relationship between corporate ownership and payout behavior due to reason that corporate owners are more efficient in controlling agency problem than individual owners. Rozeff (1982) argued that dividend provides indirect controlling benefit where active monitoring of a firm's management by its shareholders is missing. Based on agency cost hypothesis, Easterbrook (1984) established that corporate dividend policy should be designed in a way that

\footnotetext{
${ }^{*}$ Corresponding author. E-mail: hammadhassan@uos.edu.pk Tel: $+92-48-3210055$ or $+92-48-9230818$.
}

it can mitigate the agency cost of monitoring. This argument highlights the importance of ownership structure in designing corporate dividend policy. A large number of studies (See For example, Shleifer and Vishny, 1986; Brickley et al., 1988; Graves and Waddock, 1990) have argued that institutional investors, based on their professional decision making power, are more vigilant in controlling the agency cost, because they enjoy economies of scale in collecting information. By employing human resources and using sophisticated data analysis programs, they have better knowledge of evaluation of firm's performance and have an art of controlling management's affairs. It is generally argued that institutional investors have better control over managerial affairs therefore; companies with higher degree of institutional owners may have a relatively less concern about agency problem and are expected to pay less dividend.

However, tax based hypothesis supports that institutions may have incentive in receiving high dividend income based on the tax treatments. For instance, tax on dividend is deductable at source therefore; dividend income is exempted from tax while calculating net tax on total income. Many researchers have argued that corporate investors have been attracted towards higher dividend (Han et al., 1999; Dhaliwal et al., 1999; Short et al., 
2002; Allen et al., 2000). Another reason for preference of high dividend paying stocks could be the prudent man rule. Institutions are often subject to certain restrictions in their charter (like the "prudent man rule") which prevent them from investing in non-dividend paying or lowdividend paying stocks.

The two afore-hypotheses may not be viewed as mutually exclusive as the corporate dividend decision could be affected by both of them simultaneously. Based on the type of institution, the preference towards high or low dividend may also change. For instance, in firms where greater proportion of shares are held by banking companies, dividend payout might be very low, because banks seek greater security for their debt (Amihud and Murgia, 1997) in the form of high retained earnings while insurance companies prefer regular and high dividend payout to fulfill their immediate cash requirements (AlMalkawi, 2005). Moreover, the availability of growth opportunities may also affect corporate dividend policy differently. For instance, some companies would be reluctant to reduce dividend payout when growth opportunities are available and would be willing to increase payout to signal strong financial position to market in order to maintain the market value of their shares. While other companies may reduce dividend during growth phase in order to finance investment projects from internal sources, thus avoiding costly external financing. Based on combination of institutions' better monitoring and cost affective information gathering ability, some researchers have suggested strong interaction between corporate payout and institutional holdings

However, very few studies have considered the composition of institutional ownership as a determining factor of corporate dividend policy. In context of Pakistan, little evidence is available regarding the impact of institutional ownership on dividend payout of listed companies; therefore, the present study investigates the role played by different institutional investors in determining dividend payout of Pakistani companies.

Pakistan is a common law country, whose corporate practices are governed by Companies Ordinance 1984 and Security and Exchange Ordinance 1969. But unfortunately, the level of corporate governance in Pakistani companies is high as compare to developed countries. Pakistani companies possess "cross circular ownership" or which is also termed as "pyramid ownership structure" where one primary owner dominates over the affairs of company. In such situation, role of institutional owners becomes more important in controlling agency conflicts as institutions are supposed to be better informed than are individual investors. They not only devote resources to gathering information, but also sometimes they privy to corporate information that individual investors do not have (Michaely and Shaw, 1994).

The institutional investors in Pakistan mainly include insurance companies, mutual funds, Modarbah companies and other financial institutions. Insurance sector is among the rapidly growing sector of Pakistan. Its contribution towards society's welfare is massive. As risk is inherited in all types of business transactions, insurance companies work as managers of risk and help individuals and businesses to understand and handle risk efficiently (Afza and Jam, 2010). National Investment Trust (NIT) is Pakistan's oldest and biggest mutual fund; it is the market portfolio of all major companies listed at Karachi Stock Exchange (KSE). NIT is a simple way of making investment and savings; it provides professional services of funds management and diversification at a very low cost. It is convenient and suitable for investors who wish to diversify their investment risk over a longterm investment horizon. Modarbah is another rapidly growing institution of Pakistani market, the concept of Modarbah requires provision of funds by one party and the management by the other. Modarbah Control Ordinance was promulgated in 1980. The business of Modarbah is based on the philosophy of profit and loss sharing according to the teachings of Islam. In 1989, the basic concept of a Modarbah underwent a change according to which the financer and their associates were required to contribute $50 \%$ of the total capital and the remaining fund will be contributed by the general public against Modarbah Certificates. These Certificates are similar to other share certificates and their denominations are subject to the same approach like common equity shares. However, the provision for distribution of $90 \%$ of the profit and consequently the exemption of tax are among the attractive features of Modarbah Certificate. The spectrum of activities of is so wide that if a Modarbah is properly managed it can derive the benefits of Leasing Company. According to Haqqani (1993) Modarbah is a unique business that has the advantage of tax exemptions and it can be described as most attractive instrument at the present price levels. The Modarbah and other Institutions play an important role in managing the affairs of business, but unfortunately very few researchers have studied the impact of institutional ownership on dividend policy of the company.

Furthermore, during high growth phase, companies control their dividend payouts differently. For example, some companies would be reluctant to reduce dividend payout when growth opportunities are available to them; rather they would be willing to increase payout to signal strong financial position to market in order to maintain the market value of their shares, which could be beneficial for them for equity financing. While other companies would decrease the dividend payout to finance investment projects from internal sources thus avoiding costly external debts. Firms with high growth opportunities require funds to capture the best available investment opportunity with cheapest source of finance (retained earnings) therefore, during high growth phase firms would be reluctant to pay high dividend. (Mayers and Majluf, 1984). On the other side, LaPorta et al., (2000) have argued that, growing firms are more in need of 
external financing, therefore, in order to insure access to external capital market the firm might be motivated to institute a good standing with stockholders through higher dividend payouts.

The present study has used different categories of institutional ownership as determinant of dividend payout. Previous studies on dividend policy in context of Pakistan have ignored the classifications of institutional owners (Ayub, 2005; Ahmed and Attiya, 2009 and Nishat and Walliullah, 2010). This study is an attempt to capture the impact of ownership by different institutional investors and growth opportunities on dividend payouts. The estimated results are expected to provide insight in to the corporate dividend policy of Pakistani listed companies.

\section{LITERATURE REVIEW}

The existing literature on the determinants of dividend policy has its roots in the seminal paper of Lintner (1956) and Miller and Modigliani (1961). Lintner (1956) found that changes in earnings and existing dividend rates are the most important determinants of a company's dividend decision. Miller and Modigliani (1961) presented the irelevance proposition and proved that in a perfect capital market firm's dividend decision is not a thing of value at all. Regarding determinants of dividend policy, many researchers have analyzed the impact of ownership structure on dividend payouts but the evidence on the impact of proportion of shares held by different institutional owners on dividend policy is very limited.

D'Souza (1999) examined the agency cost, market risk, investment opportunities and dividend policy. She used the institutional holdings, beta and market to book value as proxy for agency cost, market risk and investment opportunities respectively. The results of the study clearly show a negative relationship between agency cost and market risk with dividends payout. However, the estimated results do not support the negative relationship between dividend payout policies and investment opportunities. The relationship between dividend policy and investment opportunities for international firms in sample is found to be statistically insignificant.

An empirically investigation using Multex Investor Database was conducted by Myers and Frank (2004) on a sample of 483 firms. They applied OLS regression techniques to analyze the impact of P/E ratio and Institutional ownership on dividend decision of companies. They found that higher the Price to Earning ratio higher will be the corporate payouts and higher institutional and insider's ownership lead to lower payout ratio. Based on the results they established that managers have an incentive to reduce dividends in order to increase the expected value of their stock options received as executive compensation. However, debt to equity ratio was found to be positively related with dividend payout for which they have argued that firms are willing to use debt to finance increasing dividends so that a strong positive signal may be sent to investors regarding strength of future earnings which helps companies to enhance reputation and maintain access to capital.

Elston et al. (2004) examined the impact of Institutional Ownership on dividend payout of 100 German companies from 1970 to 1986. Using Propensity Score Matching (PSM) method, they found no significant impact of institutional ownership and banking control on dividend payouts. However, the estimated results suggested that lack of tax incentives, favoring dividend income serves to reduce the agency problem, resulting in better alignment of institutional and minority shareholders interests. Major findings were consistent with the facts regarding the nature of the German firms which reduce the agency cost of conflicting interest between management and shareholders interest regarding use of free cash flows by giving the right to management to retain significant percentage of the net profits of the firms.

From developed economy of US, Grinstein and Roni (2005) examined the relationship between institutional ownership and dividend payout of US public firms. Using Thomson Financial Data base, they examined financial data of publically traded companies from 1980 to 1986 comprising of 79,010 firm year observations and found that although institutional investors avoid firms that do not pay dividend, among dividend paying firms yet, they prefer firms that pay fewer dividends. They also prefer firms that repurchase shares on regular basis. However, higher institutional shareholdings and concentration of shareholdings do not increase dividend payouts.

The ownership structure of 330 large listed UK firms was analyzed by Khan (2006). Based on the estimated results she reported that ownership concentration has a negative impact on firm's dividend paying ability. She further analyzed ownership compositions and reported that ownership by insurance companies is positively and individual ownership is negatively related with dividend policy.

From emerging economy of India, Kumar (2006) investigated the impact of corporate governance on dividend payouts. He used panel data of Indian firms from 1994 to 2000 and found the firm's financial structure, investment opportunities, dividend history, earning trends, and the ownership structure are the most significant determinants of dividend behavior. He reported that earning trends are positively and investment opportunities are negatively related with debt-equity ratio, and an inverse relationship of institutional ownership and dividend payout was observed in Indian companies.

Han et al. (1999) studied the relationship between institutional ownership and dividend payouts. Using the Tobit analysis they found positive relationship between institutional ownership and corporate dividend policy. Results show that dividends are positively related to institutional ownership, thus supporting the tax-based hypothesis that institutional shareholders prefer dividends over capital 
gains because of the differential tax treatment. Thus, their results support a certain type of "dividend clientele."

From emerging economy of Pakistan, Ahmed and Attiya (2009) studied the determining factors of dividend policy. Using a sample of 320 firms listed at KSE from 2001 to 2006, they first analyzed the Lintner, Fama and Babiak proposed models, which were the extension of partial adjustment model, using Panel Regression. The estimated results show that in Pakistan companies rely more on current earnings and past dividend to fix their dividend payment. Secondly, they studied determinants of corporate payouts and found that firms with stable positive net earnings pay larger dividends. Regarding ownership concentration and market liquidity, a positive relationship of both was observed with dividend payout ratio. However, no significant impact of growth opportunities was found on payouts. Contrary to the existing literature they reported negative relationship of size with dividend policy for which they argued that in Pakistan, large companies prefer to invest in their assets rather then to pay dividends.

Nishat and Walliullah (2010) examined dividend behavior of 535 Pakistani firms during 1985 to 2005 based on Probit regression model. The estimated results show that profitability, liquidity and firm leverage are the strongest and most influential predictors of dividend behavior in Pakistan. Companies with higher equity pay fewer dividends while large companies are expected to pay higher dividends. The results also suggest that government ownership in companies increases the dividend payouts but companies with surplus growth opportunities do not necessarily increase their dividend payouts. They found financial reforms as positively related to the dividend decision based on which they argued that secondary market development has a significant effect on dividend decision.

More recently, Asif et al. (2011) examined relationship between dividend policy and financial leverage of 403 listed companies of KSE for the period 2002 to 2008. They used dividend yield and debt ratio of previous year and change in earnings to determine the level of dividend per share. Base on results from panel regression they found significantly negative relationship between corporate debt and dividend payouts. However, no affect of change in earnings on dividend payments was observed.

From the above discussion on existing literature, one can understand the complexity of dividend puzzle. Although institutional owners play a vital role in enhancing corporate performance, but it is important to study the nature of business and preferences of such institutional owners, which distinct them from each others. Analyzing the role of institutional owners as a whole in determining corporate payout policy may produce biased results. The present study particularly attempts to analyze the role played by different types of institutional investors in determining corporate payout policy. To the best of authors' knowledge, no study to date has analyzed the impact of ownership by institutional categories on dividend payouts in Pakistan.

\section{METHODOLOGY}

The data of 120 companies representing all major sectors of Karachi Stock Exchange (KSE) has been collected for the period 2002 to 2007, using the following criteria:

1. Company was listed at KSE during years 2002 to 2007.

2. Ownership data for at least 3 years was available.

3. Should not be in loss in for the whole study period.

4. Should not have missed dividend payment for more then 3 years.

5. Should not be a state owned enterprise.

The data has been collected mainly from the published financial statements, annual reports, publications of State Bank of Pakistan (SBP) and from daily quotations of KSE.

\section{Variables of the study}

The present study considers dividend payout (DPO) as the dependent variable, which is a commonly used proxy of dividend policy; many financial researchers have used dividend payout as a proxy of corporate dividend policy (Gugler, 2003; Reddy and Rath, 2005; Papadopoulos and Dbmitrios, 2007; Al-Malkawi, 2007; Ahmed and Attiya, 2009). However, DPO is an accounting measure subject to be affected by corporate earning management strategies. To avoid any biasness in results and for robustness of results we have also used dividend intensity (DIVINT) as an alternative measure of dividend policy in Pakistan.

Institutional investors are generally attracted towards high dividends which might be due to fiduciary reasons or prudent man rule. But based on the type of institution and nature of its business, this prediction may be vague. For example, banks may like more security in the form of assets and reserves maintained at the expense of low dividend payments whereas, insurance companies and pension funds can be attracted towards high dividend because of their cash requirements for settlement of claims etc. (Al-Malkawi, 2007). Therefore, the impact of number of shares held by institutional investors as a whole on dividend payout could be misleading. Based on the above argument, it does not seem intuitively appealing to use institutional ownership in total as a determinant of payout policy. The present study has segregated the institutional owners in to four major categories that is, insurance companies, Modarbah com-panies, National Investment Trust, and miscellaneous companies which include financial institutions, banks and other joint stock companies.

Firm's future growth opportunities play an imperative role in determining corporate payouts. Firms with higher growth opportunities require funds to timely capture the best available investment opportunity with cheapest source of finance, because of which during high growth phase firms would be reluctant to pay higher dividend. In order to capture firm's growth opportunities we have used Market to Book Ratio and it is expected to have a negative relationship with dividend payouts.

Moreover, existing financial literature reported size to be inversely related with chances of bankruptcy (Ferri and Jones 1979; Titman and Wessels 1988; Rajan and Zingales 1995). Intuitively, larger companies due to the higher value of their assets have more access to debt markets to borrow funds as compared to small companies. Moreover, large size firms are more diversified and they also have regular and less volatile cash flows, based on which they are capable of paying higher dividends. However, debt has the tendency to leaver up shareholders return but it also brings liquidity risk to company. When firm acquires debt, it commits itself to a fixed financial charge, interest, and repayment of principal. To avoid 
Table 1. Variable explanation.

\begin{tabular}{|c|c|c|c|}
\hline \multicolumn{4}{|c|}{ Dependent variable } \\
\hline DPO & Dividend Payout & Dividend Per share/ Earning per share & \\
\hline DIVINT & Dividend Intensity & Total Cash Dividend / Total Assets & \\
\hline \multicolumn{3}{|c|}{ Independent variable } & Expected relationship \\
\hline INSUR & Insurance companies Ownership & Proportion of shares held by Insurance companies & $(+)$ \\
\hline MOD & Modarbah Ownership & Proportion of shares held by Modarbah companies & $(+)$ \\
\hline NIT & $\begin{array}{l}\text { National Investment Trust } \\
\text { Ownership }\end{array}$ & Proportion of shares held by NIT & $(+)$ \\
\hline INST $^{*}$ & Misc. Institutional Ownership & Proportion of shares held by Misc Institutions & $(+)$ \\
\hline GROW & Growth Opportunities & Market Value per Shares/Book Value of per share & $(-)$ \\
\hline SZ & Size & Log of Assets & $(+)$ \\
\hline LVRG & Leverage & Total Liabilities/ Total Assets & $(-)$ \\
\hline PRFT & Profitability & Net Profit after tax/ No. of share outstanding & $(+)$ \\
\hline
\end{tabular}

*INST represents miscellaneous institutional ownership, which includes private companies, Financial Institutions, Joint Stock Companies, Commercial Banks etc.

short term insolvency firm has to maintain good liquid position and cash flows as a result firm has to reduce its dividend payouts (Gugler and Yurtoglu, 2003; Aivazian et al., 2003). The present study has used total liabilities to total assets as a measure of companies' leverage which is expected to affect payout negatively. Profitability ensures operational success of company and is the primary source of fund generation. Company reporting loss over a long period of time may not be in good position to pay dividend due to deficiency of funds or danger of bankruptcy. Therefore, firm's profitability is expected to have a positive relationship with dividend payouts. Firm's Earning per Share (EPS) is considered as a proxy of firm's profitability. All variables have been summarized in Table 1.

\section{Model specification}

In order to analyze the impact of ownership characteristics and growth opportunities on dividend policy, five regression models have been formulated. Model 1 estimates the impact of ownership by Insurance companies, growth opportunities and three control variables i.e. size, leverage and profitability on dividend payout.

$$
(D P O)_{i t}=\alpha_{0}+\beta_{1}(I N S U R)_{i t}+\beta_{2}(G R O W)_{i t}+\beta_{3}(S Z)_{i t}+\beta_{4}(L V R G)_{i t}+\beta_{5}(P R F T)_{i t}+\varepsilon_{i}
$$

Model 2 estimates the impact of Modarbah ownership on dividend

leverage and profitability. payouts while controlling for corporate

$$
(D P O)_{i t}=\alpha_{0}+\beta_{1}(M O D)_{i t}+\beta_{2}(G R O W)_{i t}+\beta_{3}(S Z)_{i t}+\beta_{4}(L V R G)_{i t}+\beta_{5}(P R F T)_{i t}+\varepsilon i t
$$

size, Similarly, in equation 3 and 4 the ownership by NIT and

miscellaneous institutions respectively, are used as independent variables:

$$
(D P O)_{i t}=\alpha_{0}+\beta_{1}(N I T)_{i t}+\beta_{2}(G R O W)_{i t}+\beta_{3}(S Z)_{i t}+\beta_{4}(L V R G)_{i t}+\beta_{5}(P R F T)_{i t}+\varepsilon_{i t}
$$

$$
(D P O)_{i t}=\alpha_{0}+\beta_{1}(I N S T)_{i t}+\beta_{2}(G R O W)_{i t}+\beta_{3}(S Z)_{i t}+\beta_{4}(L V R G)_{i t}+\beta_{5}(P R F T)_{i t}+\varepsilon i t
$$

Finally in model 5 the joint impact of all institutional ownerships has been estimated. To check the robustness of results models 1 to 5 are re-estimated using alternative proxy of dividend policy i.e. Dividend intensity. Model 5 as follows:

$$
\begin{aligned}
& (D P O)_{i t}=\alpha_{0}+\beta_{1}(I N S U R)_{i t}+\beta_{2}(M O D)_{i t}+\beta_{3}(N I T)_{i t}+\beta_{4}(I N S T)_{i t}+ \\
& \beta_{5}(\text { GROW })_{i t}+\beta_{6}(S Z)_{i t}+\beta_{7}(L V R G)_{i t}+\beta_{8}(P R F T)_{i t}+\varepsilon_{i-}-\ldots+-
\end{aligned}
$$

\section{Estimation techniques}

Existing literature reveals that OLS is the widely used technique to investigate the determinants of dividend policy (Kumar, 2006; AlMalkawi, 2007; Anil and Sujjata, 2008 and Ahmed and Attia, 2009; Nishat and Walliullah, 2010). Therefore, the present study has used 
OLS as the primary statistical tool of analysis. However, in considering dividend payouts it is important to note that firms can pay either a positive dividend or no dividend, but in no case firm can pay a negative dividend. If the company is in loss its payout ratio, which is an accounting measure, will become negative, which is against common understanding. In Pakistan, many companies do not pay dividends and even those who pay dividends do not pay on regular basis and many of dividend paying companies are in loss. This gives dependent variable (DPO) a special characteristic in that it takes two outcomes. It is either equal to zero or positive. Dividend can never be negative (Al-Malkawi, 2007). To handle this issue, present study has also used Tobit model which is supported by existing financial researchers (Maddala, 1992; Anderson, 1986; Huang, 2001)

\section{Tobit model}

Although, OLS is a widely used estimation technique in financial research, however, it has a limitation in case where dependent variable is censored either from lower tail of distribution or upper tail or both. It is also the case where observed value of dependent variable is totally ignored and a representative value is recorded in place of it. In both cases OLS technique will yield a downwardbiased estimate of the slope coefficient and an upwards-biased estimate of the intercept (Dougherty 2001). In order to control this biasness James Tobin in 1958 has introduced an alternative technique which was later known as Tobit model. The estimation generally, involves censoring of data from its lower tail; this implies that DPO is censored to minimum of zero because a company can pay only positive dividend or no dividend at all. The Tobit specification is as follows:

Yit $=0, \quad$ if $y^{*}$ it $\leq 0$

Yit $=y^{*}$ it, if $y^{*}$ it $>0$

To estimate $\beta$ the maximum likelihood estimation (MLE) method is applied using statistical software that is, STATA and EasyReg. International (Easy Regression International)

\section{RESULTS AND ANALYSES}

Table 2 presents the summary statistics of all variables used in the analysis. The table is dividend in to two panels. Panel A reports the mean and standard deviation for the dependent and each of the independent variables. In order to ensure the absence of strong multicolinearity among independent variables panel B presents the correlation coefficients among variables. The highest correlation value is among growth and profitability that is, 0.355 which shows that our model is affected by multicolinearity. Furthermore, we have also calculated the variance inflation factor (VIF) of each variable (not reported) and Durbin Watson test of autocorrelation.

Table 3 presents the estimated results of five regression models using OLS regression. Equation 1 shows the ownership by Insurance companies is positively related with dividend payout and significantly related with dividend intensity which means that insurance companies in Pakistan prefer to receive cash dividend. Due to the nature of their business, insurance companies require regular cash flows in order to satisfy their claims; as a result companies in which more shares are owned by insurance companies are more likely to pay cash dividends, which is inline with the results of Khan (2006). Furthermore, dividend payout is also positively affected by firm's growth opportunities, which contradicts our hypothesis. The positive relationship of MBR shows that during the phase of growth companies do not reduce their dividend payout, but instead try to signal good financial position to their investors in order to acquire more equity to finance positive NPV projects. This result is inline with LaPorta et al. (2000) who argued that, high growth firms are more in need of external financing, therefore, in order to insure access to external capital market the firm might be motivated to institute a good standing with stockholders through higher dividend payout. The present study uses three control variables. Firstly, size of company, which was expected to have positive relationship with payouts but contrary to our expectation, size has a negative but insignificant relationship with DPO. It shows that company size does not determine the level of its payout. The relationship of size with payout is arguable, as some researchers have reported negative relationship of size with payout (Naceur, 2006; Avazian et. al., 2006; Ahmed and Attiya, 2009) while majority of others researchers have reported positive relationship of size with corporate payouts (Stacescu, 2006; Al-Malkawi, 2007 etc.).

Secondly, Leverage has a negatively relationship with corporate dividend payouts in Pakistan, which is in accordance with our expectation. This shows that highly leveraged firms have to maintain a reasonably good liquidity in order to pay regular interest and principal as well therefore, cash dividend is not a good option for such companies, which is in line with the results reported by Ahmed and Attiya (2009) and Asif et al. (2011) but contradicts the results of Mayers and Frank (2004) who have found leverage as a positive determinant of dividend payouts. Profitability is positively related with dividend payout but the relationship is significant with dividend intensity only.

In Equation 2, we have replaced the insurance companies' ownership with ownership by Modarbah companies. Keeping all other variables same, it is observed that Modarbah companies' ownership does not significantly affect the dividend policy of the companies. This could be due to the fact the Modarbah business is not well established in Pakistan and their ownership proportions in other companies are very low because of which they do not have much emphasis on corporate payouts.

Equation 3 and 4 present the impact of ownership by NIT and misc institutions respectively and again found no significant impact of ownership by NIT and misc institutions on dividend policy of Pakistani companies. NIT on average has a very nominal shareholdings in listed companies of KSE, although it is a market portfolio having its shares in almost every listed company in Pakistan but still due to it small voting power, NIT is unable to affect dividend policy of the companies. Similarly, miscellaneous 
Table 2. Descriptive statistics.

\begin{tabular}{|c|c|c|c|c|c|c|c|c|c|c|}
\hline & \multicolumn{2}{|c|}{ Panel A descriptive } & \multicolumn{8}{|c|}{ Panel B correlation } \\
\hline & Mean & Std Dev & DPO & INSUR & MOD & NIT & INST & GROW & SZ & LVRG \\
\hline DPO & 0.2443 & 1.6431 & & & & & & & & \\
\hline INSUR & 0.0202 & 0.0263 & 0.217 & & & & & & & \\
\hline MOD & 0.0182 & 0.0330 & -0.040 & 0.109 & & & & & & \\
\hline NIT & 0.0612 & 0.0658 & -0.009 & 0.197 & 0.275 & & & & & \\
\hline INST & 0.1551 & 0.1861 & 0.030 & 0.286 & 0.172 & 0.001 & & & & \\
\hline GROW & 4.8711 & 41.211 & 0.114 & 0.023 & -0.126 & -0.105 & -0.020 & & & \\
\hline SZ & 22.375 & 1.3368 & 0.072 & -0.073 & 0.151 & -0.160 & 0.246 & 0.118 & & \\
\hline LVRG & 0.5472 & 0.2371 & -0.131 & -0.060 & 0.009 & 0.050 & -0.004 & 0.069 & 0.181 & \\
\hline PRFT & 13.975 & 1.6331 & 0.068 & -0.048 & -0.050 & -0.083 & 0.002 & 0.355 & 0.160 & -0.183 \\
\hline
\end{tabular}

institutions which include banks, joint stock companies and other financial institutions have on average high shareholdings in companies' shows no significant relationship with dividend payout and dividend intensity. This result supports the findings of Grinstein and Roni (2005) who indicated that institutions prefer firms that repurchase shares and higher institutional holdings do not cause firms to increase their total payouts.

The joint impact of ownership of all institutional investors are estimated in Equation 5 which confirms our previous findings where only insurance companies ownership, leverage and profitability are observed as significant determinants of dividend policy of Pakistani companies.

However, the relationship of size with dividend intensity is found to be significantly negative. In the context of dividend policy of Pakistani companies, Ahmed and Attiya (2009) have also found that company size is negatively related with company's payout. The possible reason for this negative relationship could be the preference of large companies to retain dividends in order to avoid costly debt financing for investment in their assets. Another explanation of negative coefficient of size could be the period of study that is, 2002 to 2007, , in which economy started recovering and reached to its boom, as Gross Domestic Product (GDP) growth rate of Pakistan reached up to it ever highest level of $6.9 \%$ (in 2007) which was also recorded as the highest GDP growth in Asia (Economic Survey of Pakistan, 2007-08). But unfortunately the ongoing terrorism, political instability and worst energy crisis brought this rate down again to 5.8\% in 2008 and Pakistan's economy was hit by the worst crises of its history (cited in Afza and Hammad, 2010). Therefore it can be assumed that, large companies might be expecting this dramatic decline therefore they might have started building up reserves instead of paying dividends. However, small firms being myopic tried to attract investors through high dividend as they don't have easy access to external capital markets (Afza and Hammad, 2010). The lower panel of each model explains the $R^{2}$, Adjusted $\mathrm{R}^{2}$ of the results along with Durbin-Watson test of autocorrelation. The $\mathrm{F}$ statistics of each model in significant at the $1 \%$ level.

Table 4 presents the results from Tobit regression model based on maximum likelihood estimation. The dependent variable DPO has been censored from the lower side that is, the accounting value of dividend payout is either zero or positive. Based on the argument that company can pay only positive dividend and cannot pay negative dividend, the censored regression approach is adopted to check the validity of the results of OLS regression.

The results of first equation again depicts that insurance companies' ownership is positively related with dividend payout of the companies and companies which have growth opportunities increase their payouts, but highly leveraged firms are less likely to pay higher dividends. However, impact of ownership by Modarbah companies, NIT and miscellaneous institution do not significantly affect corporate payouts in Pakistan, as represented in Equation 2 to 4 . Leverage remained a significant determinant of dividend payout in all equations except the last equation. The overall results using Tobit model are more significant as compared with the results from OLS regression. This suggests that Tobit model is more suitable in case where dependent variable assumes either an upper or a lower limit and maximum likelihood should be used for estimation rather than ordinary least square. Lower panel of each equation gives the pseudo R2 value, Likelihood ratio, significance of chi square and log-likelihood.

\section{Conclusion}

Although it is very importance to pay dividends for a corporation, but unfortunately in Pakistan, corporate dividend payouts are low both in terms of value and number of companies. The number of dividend paying companies has decreased from $46 \%$ (2005) to $40 \%$ (2007) (KSE annual report, 2008). The primary objective of the study is to investigate the reasons behind 
Table 3. OLS-Regression estimates.

\begin{tabular}{|c|c|c|c|c|c|c|c|c|c|c|}
\hline \multirow{2}{*}{ Variable } & \multicolumn{2}{|c|}{ Equation 1} & \multicolumn{2}{|c|}{ Equation 2} & \multicolumn{2}{|c|}{ Equation 3} & \multicolumn{2}{|c|}{ Equation 4} & \multicolumn{2}{|c|}{ Equation 5} \\
\hline & DPO & DIVINT & DPO & DIVINT & DPO & DIVINT & DPO & DIVINT & DPO & DIVINT \\
\hline \multirow{3}{*}{ CONSTANT } & 0.584 & 0.022 & 0.051 & 0.040 & $1.904^{*}$ & $0.150^{* *}$ & -0.330 & 0.012 & 2.208 & $0.215^{\star \star \star}$ \\
\hline & $(0.473)$ & $(0.471)$ & $(0.041)$ & $(0.826)$ & (2.472) & $(2.385)$ & $(-0.384)$ & $(0.246)$ & $(1.385)$ & (3.188) \\
\hline & [0.637] & [0.636] & [0.968] & [0.410] & {$[0.015]$} & {$[0.018]$} & {$[0.701]$} & [0.806] & {$[0.171]$} & [0.002] \\
\hline \multirow{3}{*}{ INSUR } & 0.032 & $0.003^{* * *}$ & ----- & & ----- & & ----- & & $0.063^{* *}$ & 0.001 \\
\hline & $(1.230)$ & (2.629) & & ----- & & & & & $(2.085)$ & $(0.788)$ \\
\hline & {$[0.221]$} & [0.009] & & & & & & & [0.041] & [0.433] \\
\hline \multirow{3}{*}{ MODR } & ---- & ----- & -0.021 & $1.332 \mathrm{E}-2$ & ----- & & ----- & & 0.008 & 0.001 \\
\hline & & & $(-1.048)$ & $(0.016)$ & & & & & $(0.267)$ & $(0.489)$ \\
\hline & & & [0.297] & [0.988] & & & & & [0.790] & [0.627] \\
\hline \multirow{3}{*}{ NIT } & ---- & ---- & ---- & ----- & 0.003 & 0.000 & ---- & & 0.007 & 0.000 \\
\hline & & & & & $(0.553)$ & $(-1.802)$ & & & $(0.405)$ & $(-0.631)$ \\
\hline & & & & & {$[0.580]$} & {$[0.211]$} & & & [0.687] & [0.530] \\
\hline \multirow{3}{*}{ INST } & & & & & & & -0.003 & $1.320 \mathrm{E}-6$ & 0.004 & 0.000 \\
\hline & ----- & ----- & ----- & ----- & ----- & & $(-1.422)$ & $(0.009)$ & $(0.468)$ & $(-1.279)$ \\
\hline & & & & & & & {$[0.156]$} & [0.993] & [0.641] & {$[0.205]$} \\
\hline \multirow{3}{*}{ GROW } & $0.048^{\star}$ & $0.008^{* * *}$ & $0.050^{*}$ & $0.008^{* * *}$ & 0.004 & $0.001^{* * *}$ & 0.006 & $0.002^{* * *}$ & 0.016 & 0.001 \\
\hline & (1.782) & $(7.630)$ & $(1.816)$ & (7.084) & $(0.989)$ & (3.172) & (1.022) & $(5.100)$ & $(0.610)$ & $(0.582)$ \\
\hline & {$[0.077]$} & {$[0.000]$} & [0.072] & {$[0.000]$} & [0.324] & [0.002] & [0.308] & {$[0.000]$} & {$[0.544]$} & [0.562] \\
\hline \multirow{3}{*}{$S Z$} & -0.000 & 0.001 & 0.029 & 0.000 & $-0.077^{* *}$ & $-0.005^{\star}$ & 0.045 & 0.001 & -0.103 & $-0.009^{* * *}$ \\
\hline & $(-0.014)$ & $(0.272)$ & $(0.490)$ & $(-0.100)$ & $(-2.114)$ & $(-1.843)$ & $(1.136)$ & $(0.593)$ & $(-1.389)$ & $(-2.846)$ \\
\hline & [0.989] & [0.786] & [0.625] & [0.802] & [0.034] & {$[0.067]$} & [0.257] & [0.554] & [0.169] & [0.006] \\
\hline \multirow{3}{*}{ LVRG } & -0.572 & $-0.059^{* * *}$ & $-0.596^{*}$ & $-0.049^{* * *}$ & -0.119 & $-0.031^{*}$ & $-0.408^{*}$ & $-0.048^{* * *}$ & $0.618^{*}$ & -0.017 \\
\hline & $(-1.651)$ & $(-4.130)$ & $(-1.674)$ & $(-3.363)$ & $(-0.608)$ & $(-1.823)$ & $(-1.723)$ & $(-3.294)$ & (1.735) & $(-1.167)$ \\
\hline & [0.101] & [0.000] & {$[0.096]$} & [0.001] & {$[0.544]$} & {$[0.070]$} & [0.086] & [0.001] & [0.087] & {$[0.247]$} \\
\hline \multirow{3}{*}{ PRFT } & 0.000 & $0.000^{* *}$ & 0.001 & $0.000^{* * *}$ & $0.003^{* *}$ & $0.001^{* * *}$ & 0.001 & $0.001^{* * *}$ & 0.003 & $0.001^{* * *}$ \\
\hline & $(0.223)$ & (2.022) & $(0.393)$ & (2.693) & $(2.074)$ & $(8.447)$ & $(0.692)$ & $(6.259)$ & $(0.756)$ & $(8.079)$ \\
\hline & [0.824] & [0.045] & [0.695] & [0.008] & {$[0.040]$} & {$[0.000]$} & {$[0.490]$} & {$[0.000]$} & {$[0.452]$} & {$[0.000]$} \\
\hline
\end{tabular}


Table 3. Contd

\begin{tabular}{|c|c|c|c|c|c|c|c|c|c|c|}
\hline $\mathrm{R}^{2}$ & 0.069 & 0.456 & 0.063 & 0.410 & 0.073 & 0.418 & 0.037 & 0.300 & 0.198 & 0.719 \\
\hline $\operatorname{Adj}-R^{2}$ & 0.034 & 0.439 & 0.028 & 0.392 & 0.042 & 0.402 & 0.016 & 0.287 & 0.105 & 0.691 \\
\hline Reg. Sum ${ }^{2}$ & 6.263 & 0.200 & 5.753 & 0.171 & 2.447 & 0.280 & 4.476 & 0.352 & 4.832 & 0.130 \\
\hline Resd. Sum ${ }^{2}$ & 84.774 & 0.201 & 84.693 & 0.191 & 31.135 & 0.350 & 117.829 & 0.512 & 19.594 & 0.045 \\
\hline $\mathrm{D} / \mathrm{W}$ & 2.044 & 1.954 & 1.663 & 1.907 & 1.962 & 1.349 & 1.952 & 1.022 & 2.047 & 1.398 \\
\hline Sig. $F$ & 0.008 & 0.000 & 0.012 & 0.000 & 0.004 & 0.000 & 0.025 & 0.000 & 0.045 & 0.000 \\
\hline
\end{tabular}

Parenthesis contain (t-Statistics); [P-Value] ${ }^{* * *}$ significant at level of $1 \% ;{ }^{* *}$ significant at level of $5 \%$; ${ }^{*}$ significant at level of $10 \%$.

decreasing corporate dividends in Pakistan. Furthermore, due to the inconclusiveness of empirical investigations regarding the role played by institutional investor in determining corporate dividend payouts and the absence of such evidences for an emerging economy like Pakistan has stimulated the need to conduct this study. The data of 120 listed companies representing all major sectors of KSE has been collected from 2002 to 2007 and analyzed using OLS and Tobit regression models. The estimated results show that Insurance companies are interested in cash dividends, and companies in which more shares are held by insurance companies are more likely to pay dividends. However, no significant relationship of shares held by NIT, Modarbah and Misc. Institutions with dividend payouts is observed. The relationship of growth opportunities with dividend payouts is significantly positive which shows that Pakistani companies do not reduce their payout to finance investment projects. Size of the company does not affect its payout significantly, while highly leveraged (Profitable) companies are less (more) likely to pay high dividends.

It is evident from the results that insurance companies prefer cash dividend, therefore, the companies in which insurance companies hold large number of shares are more likely to pay higher dividends. However, NIT and Modarbah companies, due to insignificant proportion of shares in each company, do not seem to have sufficient influence on corporate payouts. Miscellaneous institutions including banks, joint Stock Companies and other financial institutions which might have different preferences toward dividends; separate analysis of these institutions might improve the significance of results. Most of the institutional investors are government owned companies, which are interested in plough back of profits rather then receiving cash dividends. Regarding growth opportunities, Pakistani companies do not seem to decrease dividend payouts in a phase when they anticipate profitable investment opportunities. Most of the companies in Pakistan are small in size and they don't have easy access to credit market, therefore, rely heavily on equity capital for financing their investment and growth opportunities and reducing dividend during growth phase can negatively affect the share value of the companies. Profitability, however, affects the payout positively in Pakistan which is in line with the existing literature on dividend policy. It shows that more profitable companies are more likely to pay high dividends. The study also emphasized the use of Tobit model instead of OLS regression in case where dependent variable is restricted either to an upper or lower limit.
Based on the estimated results it is suggested that corporate law authorities should give incentives to institutional investors in the form of tax relaxations, conditioning on their level of investments in share market. which. The increased institutional ownership will help in improving the performance of companies as a result not only investors' confidence will enhance but it will also help in increasing the corporate dividend payouts. The scope of this study is limited to 6 years data of 120 companies listed at KSE Pakistan, and therefore, represents the determinants of dividend payouts of listed companies during the window period from 2002 to 2007 only. Future researchers can improve the results of this study by classifying miscellaneous institutions in to banking institutions, joint stock companies and associated companies. Furthermore, impact of block holders and foreign companies' ownership on dividend policy is yet to be explored.

\section{ACKNOWLEDGEMENT}

This paper has been presented in " $17^{\text {th }}$ Annual South Dakota International Business Conference 2010 held from $30^{\text {th }}$ September, 2010 to $3^{\text {rd }}$ October, 2010 in Rapid City, SD, USA and is also a part of MS dissertation of Hammad Hassan 
Table 4. Tobit Regression estimates.

\begin{tabular}{|c|c|c|c|c|c|}
\hline Variable & Equation 1 & Equation 2 & Equation 3 & Equation 4 & Equation 5 \\
\hline \multirow{3}{*}{ CONSTANT } & 0.345 & 0.201 & $1.523^{\star * *}$ & 0.449 & 0.389 \\
\hline & $(0.71)$ & (0.39) & (2.85) & (1.11) & $(0.42)$ \\
\hline & [0.480] & [0.695] & [0.005] & [0.268] & [0.676] \\
\hline \multirow{3}{*}{ INSUR } & $0.427^{\star * *}$ & --- & ---- & ---- & $6.620^{\star * *}$ \\
\hline & $(3.76)$ & & & & (3.27) \\
\hline & [0.000] & & & & [0.002] \\
\hline \multirow{3}{*}{ MODR } & ----- & 0.003 & ----- & ----- & 0.003 \\
\hline & & $(0.34)$ & & & $(0.24)$ \\
\hline & & [0.737] & & & [0.813] \\
\hline \multirow{3}{*}{ NIT } & ---- & ---- & 0.002 & ----- & 0.000 \\
\hline & & & $(0.67)$ & & $(0.06)$ \\
\hline & & & [0.503] & & [0.952] \\
\hline \multirow{3}{*}{ INST } & ---- & ---- & ---- & -0.149 & -0.037 \\
\hline & & & & $(-1.19)$ & $(-0.74)$ \\
\hline & & & & [0.237] & [0.463] \\
\hline \multirow{3}{*}{ GROW } & $0.049^{* * *}$ & $0.052^{\star * *}$ & $0.009^{* *}$ & $0.007^{*}$ & $0.057^{\star \star}$ \\
\hline & $(4.79)$ & $(4.74)$ & (2.95) & (1.84) & (2.96) \\
\hline & [0.000] & {$[0.000]$} & [0.017] & [0.067] & [0.015] \\
\hline \multirow{3}{*}{$S Z$} & -0.002 & 0.004 & $-0.059^{*}$ & -0.003 & -0.017 \\
\hline & $(-0.09)$ & $(0.17)$ & $(-2.42)$ & $(-0.817)$ & $(-0.41)$ \\
\hline & [0.925] & [0.867] & [0.050] & [0.865] & [0.686] \\
\hline \multirow{3}{*}{ LVRG } & $-0.597^{\star * *}$ & $-0.468^{\star * \star}$ & $-0.257^{\star \star *}$ & $-0.433^{* * *}$ & -0.182 \\
\hline & $(-4.51)$ & $(-3.38)$ & $(-1.98)$ & $(-3.86)$ & $(-0.831)$ \\
\hline & {$[0.000]$} & [0.001] & [0.000] & {$[0.000]$} & [0.410] \\
\hline \multirow{3}{*}{ PRFT } & 0.000 & 0.000 & $0.003^{\star * *}$ & $0.004^{\star \star \star}$ & 0.000 \\
\hline & $(0.07)$ & $(0.26)$ & $(4.15)$ & (3.60) & $(0.05)$ \\
\hline & [0.944] & [0.794] & {$[0.000]$} & [0.000] & [0.960] \\
\hline PseudoR & 0.253 & 0.1564 & 0.1566 & 0.1275 & 0.3215 \\
\hline $\mathrm{LR}-\left.\mathrm{CH}\right|^{2}$ & 62.41 & 37.93 & 37.11 & 45.25 & 43.09 \\
\hline Prob. $\mathrm{CHI}^{2}$ & 0.000 & 0.000 & 0.000 & 0.000 & 0.000 \\
\hline
\end{tabular}

Parenthesis contain (t-Statistics); [P-Value] ${ }^{* *}$ significant at level of $1 \%$; ${ }^{* *}$ significant at level of $5 \%$; * significant at level of $10 \%$.

Mirza titled "Determinants of Corporate Dividend Policy in Emerging Economy of Pakistan"

\section{REFERENCES}

Afza T, Hammad HM (2010). Impact of ownership structure and cash flows on dividend payout behavior in Pakistan. Int. Bus. Res., 3(3): 210-221.

Afza T, Jam KAA (2010). Technical Efficiency of Non-Life insurance companies in Pakistan, 3rd Int. Colloq. on Bus. and Manage. (ICBM), $25^{\text {th }}$ to $28^{\text {th }}$ January, 2010, Bangkok, Thailand.

Ahmed H, Attiya J (2009). Dynamics and Determinants of Dividend Policy in Pakistan (Evidence from Karachi Stock Exchange Non Financial Firms). Int. J. Financ. Econ., 25: 148-171.

Aivazian V, Booth L, Cleary S (2003). Do emerging market firms follow different dividend policies from U.S. firms? The J. Financial Res. 26(3): 371-387Allen F, Antonio EB, Ivo W (2000). A Theory of Dividends Based on Tax Clienteles. J. Financ. 55: 2499-2536.

Al-Malkawi HAN (2007). Determinants of Dividend Policy in Jordan, An application of Tobit Model. J. Econ. Adm. Sci. 23(2): 44-70

Amihud Y, Maurizio M (1997). Dividends, Taxes, and Signaling: Evidence from Germany. J. Financ. 5: 397-408.

Anderson GJ (1986). An Application of the Tobit Model to Panel Data: Modeling Dividend Behaviour in Canada, Working Paper, MacMaster University.

Anil K, Sujata K (2008). Determinants of dividend payout ratio-A study of Indian Information Technology Sector. Int. Res. J. Financ. Econ. 15: 63-71.

Asif A, Rasool W, Kamal Y (2011). Impact of Financial Leverage on Dividend Policy: Empirical Evidence from Karachi Stock ExchangeListed Companies. Afr. J. Bus. Manage. 5(4): 1312-1324.

Ayub M (2005). Corporate Governance and Dividend Policy. Pak. Econ. and Soc. Rev. 1:115-128.

Brickley JA, Ronald CL, Clifford WS (1988). Ownership Structure and Voting on Anti-Takeover Amendments. J. Finan. Econ. 267-291.

Dhaliwal DS, Merle E, Robert T (1999). A Test of the Theory of Tax Clienteles for Dividend Policies. Nat. Tax J., 52:179-194.

Easterbrook FH (1984). Two Agency- Cost Explanations of Dividends. Am. Econ. Rev. 74:650- 659.

Elston JA, Richard H, Junsoo L (2004). Institutional Ownership, Agency 
Costs and Dividend Policy, online discussion paper. (Online), http: //ideas. repec. org/ p/ esi/ egpdis/ 2004-27.html

Ferri MG, and Jones WH (1979). Determinants of Financial Structure: A New Approach. J. Financ. 34: 631-44.

Graves SA, Waddock SA (1990). Institutional Ownership and Control: Implications from Long-term Corporate Strategy. Acad. Manag. Exec. 4:75-83.

Grinstein Y, Roni M (2005). Institutional Holdings and Payout Policy. J. Financ., Lx(3):1389-1426.

Gugler K (2003). Corporate Governance, Dividend Payout Policy, and the interrelationship between dividend, R\&D and Capital Investment. J. Bank. Financ, 27: 1197-1321.

Han KC, Suk HL, David YS (1999). Institutional Shareholders and Dividends, J. Finan. Strateg. Decis., 12(1): 53-62.

Haqqani AQ (1993). Modaraba Certificate as an Instrument for Investment Banking and Finance: Islamic Concept. Zaman, Mukhtar, Karachi, Int. Assoc. Islamic Banks (Asian Region), pp. 166-170.

Huang HCR (2001). Bayesian Analysis of the Dividend Behaviour. Appl. Finan. Econ. 11: 333-339.

Khan T (2006). Companies dividend and ownership structure: Evidence from UK panel data. Econ. J., 116: C172-C189.

Kumar J (2006). Corporate Governance and Dividend Policy in India. J. Emer. Market Financ. 5(5): 15-58.

La Porta R, Lopez De-SF, Shleifer A, Vishny RW (2000). Agency Problems and Dividend Policies Around the World. J. Financ. 55: 133.

Lintner J (1956). Distribution of Incomes of Corporations Among Dividends, Retained Earnings and Taxes. Am. Econ. Rev., 46(2): 97113.

Maddala GS (1992). Introduction to Econometrics. John Wiley \& Sons Ltd., West Sussex.

Michaely R, Wayne HS (1994). The pricing of initial public offerings: Tests of the adverse selection and signaling theories. Rev. Finan. Stud., 7: 279-319.
Myers M, Frank B (2004). The Determinants of Corporate Dividend Policy. Acad. Accout. Financ. Stud. J., 8(3): 17-28.

Naceur SB, Goaied M, Belanes A (2006). On the Determinants and Dynamics of Dividend Policy. Int. Rev. Financ., 6: 1-23.

Nishat M, Walliullah M (2010). Corporate Finance in emerging markets: An analysis of dividend policy among public listed firms in Pakistan. 3rd Int. Colloq. on Bus. and Manag. (ICBM), Bangkok 2010, Thailand.

Papadopoulos DL, Dbmitrios PC (2007). Focus on present status and Determinants of Dividend Payout Policy: Athens Stock Exchange in Perspective. J. Finan. Manag. Anal., 20(2): 24-37.

Rajan RG, Zingales L (1995). What Do We Know About Capital Structure? Some Evidence from Int. Data. J. Financ., 50: 1421-1460.

Reddy Y, Rath S (2005). Disappearing Dividends in Emerging Markets. Emerg. Mark. Financ. Trade, 41(6): 58-82.

Rozeff M (1982). Growth, Beta and Agency Costs as Determinants of Dividend payout Ratios. J. Finan. Res., 5: 249-259.

Shleifer A, Vishny RW (1986). Large Shareholders and Corporate Control. J. Pol. Econ. 94: 464-488.

Short H, Hao Z, Kevin K (2002). The Link Between Dividend policy and Institutional Ownership. J. Corp. Financ., 8:105-122.

Stacescu B (2006). Dividend Policy in Switzerland. Finan. Mark. Port. Manag. 20: 153-183.

Titman S, Wessels R (1988). The Determinants of Capital Structure. J. Financ. 43: 1-19. 